\title{
APPLYING DEBATE-TECHNIQUE IN IMPROVING THE STUDENTS' COMPREHENSION ON ORAL EXPOSITORY TEXT FOR XI GRADE STUDENTS OF MBI AMANATUL UMMAH SURABAYA
}

\author{
Tutik Mariani, M.Pd \\ SMP Plus Al-Fatimah Bojonegoro \\ 2t.marianne@gmail.com
}

Nurul Azizah Ria Kusrini, M.Pd

Institut Pesantren KH. Abdul Chalim Mojokerto

nurulazizah@ikhac.ac.id

\section{Abstract}

This study is done to know the result on applying the debating technique in teaching expository text for XI grades students of MBI Amanatul Ummah Surabaya. From the observation through the video-tapping and also the rubric for the students' response, it can be seen that the technique works really well in improving the students' comprehension on the expository text. The use of the technique not only improves the comprehension in the oral skill but also in the other skills as well. The teaching-learning runs well as the students are really engaged in the classroom activity. Keywords: Debate, comprehension, speaking skill.

\section{Introduction}

English has become the worldwide language that influences many aspects in the life including teaching field. As a foreign language, sometime it is difficult to get the students understand about the language, especially when we are talking about genres in English language teaching in Indonesia right now. There are about thirteen genres that the students must comprehend in order to pass the final examination in the end of their high school. The thirteen genres are : narrative, recount, descriptive, report, procedure, explanation, review, news item, expository (including analytical exposition and hortatory exposition), discussion, spoof, and anecdote. From those genres, this study will focus only on one genre, expository text, for the students of grade XI in MBI Amanatul Ummah especially in the speaking skill.

For general information, the method used to teach English in MBI Amanatul Ummah Surabaya is quite different to other secondary high schools. English is usually taught by integrating four skills, whereas in MBI Amanatul Ummah, each skill is taught differently by different teachers. Therefore, the school gives the teachers free to choose what method they will use to arouse the students' motivation to speak. Debate, for instance, is a method which is 
implicated to teach oral expository text to let the students utter their argumentation free about the topics given. This study is a class research which is written based on some theories and facts in the process of the research. The research is basically done to find out if debate is recommended method to help the students to rehearsal on how to state their opinion toward the particular topics and to expose the real example to support their arguments.

Reviewing to the real situation, when the students are explained textually during the lesson, they seem really understand about this expository text, whereas in oral or in written text analysis, the students still get confused although they have good skill in vocabulary. In short, it is hard to get them through into this genre since they do not know how to persuade people, and to convince others that the case is. Ideally, in learning English, students must master in both productive and receptive skills. Thus, comprehending text conceptually by answering questions based on the text is not enough to entitle that the students have understood this type of text. Further action is needed, speaking activities, to evoke their productive skill to assure their friend. One of techniques this study believe can help to enhance the students to express their opinions is debate, as they are familiar with it. The students probably not know the real rules of debate, but in their daily life they do debating each other, the point that they must underline is that they have to make other people agree with their opinion. That is the rough purpose of a debate. So, through this technique, I hope that the students learn how to give arguments with good evidences, like an expository text.

In this study, I would like to find the answer for some questions about how debating technique influence the students' comprehension on the expository text and how the students' response is in learning expository text using debating technique. The purposes of the research are to know the influence of debate technique toward the students' comprehension on the expository text; and to know the students' response in learning expository text using debating technique.

\section{Review of Related Literature}

Before we go so far, let me define previously about some definitions related to literature. Debating is about developing communication skills. It is about assembling and organizing effective arguments, persuading and entertaining an audience, and using your voice and gestures 
to convince an adjudicator that your arguments outweigh your oppositions. Debating is not about personal abuse, irrational attacks or purely emotional appeals.

A debate is held between two teams of three members each. These two teams will be referred to as the Affirmative and the Negative. Members of each team are assigned positions as 1st, 2nd, and 3rd speakers. For each debate, a motion is given. After the motion is given, teams are given thirty (30) minutes to prepare for each debate (UI, 1998), while comprehension means a skill to understand everything that usually informed written or oral (Longman Dictionary)

Davesa (2012) in her blog mentioned that debate is an activity as an argumentation form from two different point of view but informed with some rules. The main point of a debate is how we defend what we believe as a truth with clear evidences. A debater must be able to persuade the audiences that his/her arguments are the truth.

A debate is held between two teams of three members each. These two teams will be referred to as the Affirmative and the Opponent. Members of each team are assigned positions as 1st, 2nd, and 3rd speakers. For each debate, a motion is given. After the motion is given, teams are given thirty (30) minutes to prepare for each debate.

Each of the speakers will deliver a substantial speech of seven (7) minutes duration and either the 1 st or the 2 nd speaker on both sides will deliver the reply speeches for their teams. Reply speeches will be five (5) minutes.

Thus, the complete order of speaking during a debate is as follows:

- 1st Affirmative - 7 minutes

- 1 st Opponent -7 minutes

- 2nd Affirmative - 7 minutes

- 2nd Opponent -7 minutes Substantial

- 3rd Affirmative - 7 minutes

- 3rd Opponent-7 minutes

- Opponent Reply - 5 minutes

- Affirmative Reply - 5 minutes

Reply Speeches

According to (Khalil, 2011), here are the characteristics of debate: 
1. Each team consist of three members; first speaker, second speaker and third speaker

2. Team that agrees with the motion is called affirmative team while the team that against the motion is called opponent.

3. Debate procedure:

\section{First Affirmative's duties:}

- Defines the motion of the debate. The $1^{\text {st }}$ Affirmative should ensure that no important points of definition are left out.

- Presents the Affirmative's theme line. This is usually to explain why the Affirmative's case is logically correct.

- Outlines the Affirmative's team split. This is to divide the team member's part of delivering the arguments.

- Delivers substantial arguments (" 1 st Affirmative's part of the split"). After establishing the definition, theme line, and team split, the $1^{\text {st }}$ Affirmative should deal with the arguments/points that have been assigned to him/her in the team split.

- Provide a brief summary/recap of the speech.

The $1^{\text {st }}$ Affirmative may spend some time on the definition and on establishing the theme line and showing how it is going to develop, but it is important to leave time to present some substantive arguments.

First Opponent's duties:

- Provide a response to the definition (accepts or challenges the definition).

- Rebuts $1^{\text {st }}$ Affirmative, delivers a part of the negative's substantive case.

- Presents the Opponent's theme line.

- Outlines the Opponent's team split.

- Delivers substantial arguments (“ $1{ }^{\text {st }}$ Opponent's part of the split").

- Provide a brief summary/recap of the speech. 
The $1^{\text {st }}$ Opponent's role is similar to the role of the $1^{\text {st }}$ Affirmative's, with the added responsibility of responding to the arguments brought up by the latter. The response to the $1^{\text {st }}$ Affirmative's arguments can come before the $1^{\text {st }}$ Opponent presents his/her own arguments to support the Opponent's case or vice-versa.

After the first speakers have spoken the main direction of each team's case should be apparent.

\section{Second Affirmative's duties:}

- Rebuts the $1^{\text {st }}$ Opponent's major arguments.

- Briefly restates/reiterates in general terms the Affirmative's team case.

- Delivers substantial arguments ("2 $2^{\text {nd }}$ Affirmative's part of the split"). Most of the $2^{\text {nd }}$ Affirmative's time should be spent dealing with new substantial material/arguments. He or she has the duty to present the bulk of the Affirmative's case in an attempt to further argue in favor of the Affirmative.

- Provide a brief summary/recap of the speech.

The $2^{\text {nd }}$ Affirmative should be prepared to defend the definition if necessary. If it is attacked, it is vital for the $2^{\text {nd }}$ Affirmative to win back the initiative.

\section{Second Opponent's duties:}

- Rebuttal of the first two Affirmative speakers.

- Briefly restates/reiterates in general terms the Opponent's team case.

- Delivers substantial arguments (" $2^{\text {nd }}$ Opponent's part of the split").

- Provide a brief summary/recap of the speech.

The $2^{\text {nd }}$ Opponent duties is similar to the one performed by the $2^{\text {nd }}$ Affirmative.

Most of the teams' substantive argument should have emerged by the time both second speakers have spoken.

\section{Third Affirmative's duties:}

- Rebut the points raised by the first two Opponent speakers. The $3^{\text {rd }}$ Affirmative is mainly entrusted with the duty of responding to the arguments of the Opponent that were not 
previously dealt with by the first two Affirmative speakers. $3^{\text {rd }}$ Affirmative may also reinforce rebuttals that have already been stated by teammates.

- Rebuild team's case (briefly reiterate theme line and first two speakers' arguments).

- Summarize the issues of the debate.

Third Opponent's duties:

- Rebutt the points raised by all three Affirmative speakers.

- Rebuild team's case (briefly reiterate theme line and first two speakers' arguments).

- Identify the points of contention / the clash of the debate

- Summarize the issues of the debate

The $3^{\text {rd }}$ speaker of Opponent's duties is similar to the ones performed by the $3^{\text {rd }}$ Affirmative. However, the $3^{\text {rd }}$ speaker of Opponent cannot introduce a new matter, except for new examples to reinforce an argument that has previously been brought up. The logic behind this rule is that if a $3^{\text {rd }}$ Opponent is allowed to introduce new matter, the Affirmative would be at a disadvantage as they would not have any opportunity to be able to respond to these new arguments.

\section{Reply speakers duties (both sides):}

- Provide a summary or overview of the debate

- Identify the issues raised by both sides

- Provide a biased adjudication of the debate

Either the first or the second speaker of each side may deliver the reply speech. The Opponent team delivers the first reply speech.

A reply speech is a review of both the own case and the opposition's case. It represents a chance for the teams to show their arguments in the best light and to summarize the flaws in the opposition's case. The aim is to emphasize the major points made by your own team and to show how these contributed to a logical progression of argument in support of the theme line. At the same time the flaws in the opposition's argument must be outlined. This can be done point-bypoint, or by taking a more global approach to the arguments.

The introduction of new material is absolutely prohibited. Any point brought up by the other side which had not been rebutted earlier in the substantial speeches may not be rebutted in the reply 
speeches. Therefore, this means that all substantive arguments presented in the debate must be dealt with by the opposing team in the substantial speeches.

From the discussion above we can see that the arrangement of a debate looks like the expository text that consist of three parts; thesis is the topic or idea given (it looks like a motion), arguments is the reasons and evidences given to support the idea (just like what is done by the speakers while giving their argument) and reiteration or conclusion is restate the position of the writer just like the replier position in a debate that restate the position of their team toward the motion. So, if the debate is written, both affirmative and opponent, are fulfilled the requirement as an expository text. Or orally, it is also expository because it is used to persuade the audience as well as written expository text.

Comprehension includes the ability to catch/understand the meaning of a lesson that is learned. This ability is declared in giving the main point of a passage. According to Brown (1987), comprehension includes the goal, behavior or feedback that reflects a written message in a communication. Therefore, the students are asked to comprehend or understand what is taught, know what is being communicated and use the content of the lesson without relates it to another thing.

In this research, the writer tries to use the debating technique to improve the students understanding on the expository text. The arguments given by the affirmative team that are supported by proofs and evidences and examples, if it is read as a whole part is a form of expository text as well as the arguments given by the opponent team.

\section{Research Methodology}

This research is a classroom-action research. A classroom-action research is a reflective process that possibly rises inquiries and discussions as part of the research. (Unesa., 2012) the classroom-action research can be done by a participant to examine the education practice and their own teaching-learning systematically and carefully by using the research techniques. It is also stated the importance of the teachers of English in applying the action planning process of teaching-learning to make a better change in an English class. In this research, there are four steps that will be done, those are: planning the action, implementing, observing and reflecting. 
The research is done in MBI Amanatul Ummah Surabaya in Pacet, Mojokerto and the subject is the students of XI grades. The researcher needs two months to do the research.

Here are the action-procedures:

1. Planning phase

In this phase, the researcher works on:

- Lesson Plan

- Preparation for the motions

- Media

- Assessment rubric

- Questionnaire

2. Action and Observation phase

- Pre : the motions are given to the students, divide the team and decide which one will be the affirmative and the other will be the opponent.

- While : Debating, video-taping

- Post : questions about expository text based on the debate that the students do to measure the students' understanding.

3. Reflection

In this phase, the questionnaires are given to know the students' responses about the use of debating technique in improving the students' comprehension on expository text, conceptually and contextually

In this research, the data is taken by video-taping the students' activity in debating, the motions that is given and the rubrics that is used for the assessment. The source of the data is taken from the video of the students' activity and the rubrics that is used for the assessment. The data is collected by video-taping that will be assessed with rubrics and compared to the result of the study previously. The instruments that are used: video-tape and rubric sheets. 
How can you make sure that there are listening activities during the debating?

\section{Findings}

Comprehension in a topic is very important because it is a measurement for us to give assessment to our students. Usually the students understand the topic conceptually but do not understand it contextually. In this research, the researcher is focused on the use of debate to improve the students' comprehension in oral expository, so it is related to the speaking ability. Speaking is one of the skills that must be mastered by students who learn language because the purpose of learning a language is to communicate with others and one way of communication is by speaking. Speaking is always a problem for students and probably for some teachers on how they have to teach speaking to their students. A question on why it is difficult for students to speak in English and how is the best way to teach it is often rise among the teachers who has specialty in teaching speaking. Students tend to keep silent in the classroom that the teachers do not know whether they understand about the lesson given or not. From what I learn from my students in the XI grades, talking about expository text will bring them to the structure of the text itself such as thesis, arguments, and reiteration or conclusion. But in a real topic with a passage the students usually get confused about which part is called thesis and why, which part is called arguments and why and etc. My students in MBI Amanatul Ummah are quite good in their English and they know lot of vocabularies, and they like to compete each other therefore I try to use debate technique to make clear of the expository text.

Using the technique make the students get very excited to do the debate in the class. At first they do not know the purpose of this debate issue. The teacher comes to the class, divide them into teams and provide some motions to be chosen. The students prepare their group and choose the motion that they like. The teachers find the opponent through a lottery and explain the debate rules. As the students know the rules in debate, everything runs very well. All of the students get engage in the classroom activity. All the members of the team participate in speaking and giving their opinion to strengthen their group's position. By the end of the debate, I am as the teacher explains how the debate looks like the expository text. I take one example from the affirmative and the second example from the opponent. After that, I include the generic structures of the expository text and compare it to each part of the debate. This really works for the students that they get really understand about the expository text. Whenever it is stated about 
expository, they directly remember about the debate, the rules, the parts, and what should be stated there. From here we can see that this debating technique is really helpful to improve the students understanding on the expository text. Moreover, it also helps the students to improve their confidence in speaking in front of the public. Well, in this case, we start from the small public like a classroom but in the future the students may develop their ability in speaking in front of the real public. Though it seems that it only works for the speaking skill, it is actually works for all of the skills. The students have to read many sources to get the evidences that support their ideas means that it may develop their reading skill. They also write notes in order to be well-arranged in their speech which means that they are developing their writing skill. From the research on my students, we can see that this technique exactly works to improve the students' understanding/comprehension in expository text.

The students' response on this technique is also positive. They think that through this technique, they get really understand about the expository genre, no matter the text is about, they will remember what should be existed in the expository text as it is almost the same as the debate procedure. They said that this technique interest them much because they think that this technique improve their speaking skill. Although they feel nervous in the first time, they can manage it well because they feel that it is the right time for them to practice and improve their English. They also feel the challenge to speak in this small public speaking because they rarely have time to speak in front of the public. In short, the students like to use this technique for their expository genre.

\section{Conclusion}

From the discussion above we can see that the debating-technique works really well in improving the students understanding on the expository text. Moreover it also helps the students to develop more on their speaking ability. The other skills are improved as well such as reading, writing and listening. Reading because they have to read many sources in order to get relevant evidences and examples that support their ideas, writing because they also need to make notes as the outline of their speech and listening because they have to listen carefully about their opponent's opinion so that they can rebut or defend their opinion well. For teachers, it is also helpful to make assessment because from here we can see who is really involved in the team work. The other benefit is that it makes the teacher manage the class easier because all of the 
students are engaged in the class activity. Therefore, this technique is now used by some of the English teachers at my school, MBI Amanatul Ummah Surabaya.

It is significant for us to do the research because there are some benefits that can be taken from this research. For the students, I hope that the students will be able to analyze the expository text with different topics and understand it well contextually and conceptually. While for teachers, I hope that the standard goal can be reached. For other researcher that has the same

difficulties in making the students understand about the expository text may use the same technique to his/her students and develop the technique so that the result will be better.

\section{REFERENCES}

Brown, H. Douglas. (1987). Principles of Language Learning and Teaching. New Jersey: Prentice-Hall.

Davesa, Esa. (2012). Konsep Debat.

Khalil, Aulia Absari. (2011). Prosedur Debat.

UI, EDS. (1998). Guidelines for Debater.

Unesa., Panitia Sertifikasi Guru. (2012). Materi pendidikan dan latihan profesi Guru. Surabaya: Unesa. 